\title{
UPAYA MENINGKATKAN HASIL BELAJAR MATEMATIKA DENGAN MENGGUNAKAN MEDIA KONKRET PADA SISWA KELAS IIA SD NEGERI 064960 KECAMATAN MEDAN POLONIA
}

\author{
Megawati \\ Surel: megawati07@gmail.com
}

\begin{abstract}
ABSTRAK
Penelitian ini bertujuan untuk (1) Mendeskripsikan peningkatan aktivitas peserta didik dalam kegiatan belajar mengajar dengan menggunakan media sedotan. (2) Mengetahui peningkatan hasil belajar matematika pada peserta didik kelas II-A SDN 064960 Medan setelah menggunakan media konkret sedotan. Sedangkan dalam penelitian ini menggunakan analisis data persentase klasikal dan N-Gain. Hasil penelitian menunjukkan bahwa: (1) aktivitas peserta didik setelah menggunakan media sedotan mengalami peningkatan pada siklus I diperoleh jumlah skor 45,5 dan siklus II jumlah skor 60 dengan kategori baik, (2) ada peningkatan hasil belajar matematika melalui penggunaan media konkret sedotan yang menunjukkan dari hasil awal 28,57\%, pada siklus I 64,28\% dan siklus II $100 \%$.
\end{abstract}

Kata Kunci: Hasil belajar, Matematika, Media Konkret

\section{PENDAHULUAN}

Penggunaan media

pembelajaran khususnya media konkret sangat menarik bagi peserta didik terutama saat proses pembelajaran berlangsung sehingga menarik perhatian peserta didik dan dapat menumbuhkan keaktifan belajar peserta didik. Peserta didik merasa pelajaran matematika sangat sulit dan membosankan untuk mereka pahami karena proses pembelajaran cenderung monoton.

Ada beberapa faktor yang mempengaruhi hasil belajar peserta didik diantaranya kebanyakan guru hanya menggunakan metode ceramah pada saat pembelajaran berlangsung sehingga peserta didik kurang ada keaktifan tinggi dalam mengikuti pembelajaran khususnya dalam mata pelajaran matematika. Sehingga pada saat pembelajaran Matematika peserta didik kurang memperhatikan penjelasan guru dan asik dengan urusan mereka masing-masing.

\section{METODE PENELITIAN}

Jenis penelitian yang digunakan dalam penelitian ini adalah penelitian tindakan kelas (PTK) yang bertujuan untuk melakukan perbaikanperbaikan terhadap sistem, isi, dan kompetensi atau situasi pembelajaran dengan menguji cobakan suatu ide ke dalam praktik dan situasi nyata dalam 
proses belajar mengajar di kelas dengan harapan kegiatan tersebut dapat meningkatkan hasil proses belajar mengajar.

Menurut Arikunto (2012 :2/3) menyatakan bahwa:

1. Penelitian, menunjukkan pada suatu kegiatan mencermati suatu objek dengan menggunakan cara dan aturan metodologi tertentu untuk memperoleh data atau informasi yang bermanfaat dalam meningkatkan mutu suatu hal yang menarik minat dan penting bagi peneliti.

2. Tindakan, menunjuk pada suatu gerak kegiatan yang sengaja dilakukan dengan tujuan tertentu. Dalam penelitian berbentuk rangkaian siklus kegiatan untuk siswa.

3. Kelas, dalam hal ini tidak terikat pada pengertian ruang kelas, tetapi dalam pengertian yang lebih spesifik. Seperti yang sudah lam dikenal dalam bidang pendidikan dan pengajaran, yang dimaksud dengan istilah kelas adalah sekelompok siswa yang dalam waktu yang sama, menerima pelajaran yang sama dari guru yang sama pula.

Sedangkan menurut Kunandar (2010:41) menyatakan bahwa: "Penelitian Tindakan Kelas (Clasroom Action Research) memiliki peranan yang sangat penting dan strategis untuk meningkatkan mutu pembelajaran belajar apabila diimpementasikan dengan baik dan benar".

Subjek penelitian yang peneliti ambil dalam proposal ini adalah peserta didik yang berjumlah 30 orang.

Tabel 1. Subjek Penelitian

\begin{tabular}{|c|c|c|c|}
\hline \multirow{2}{*}{ Kelas } & \multicolumn{2}{|c|}{$\begin{array}{c}\text { Sampel } \\
\text { Penelitian }\end{array}$} & \multirow{2}{*}{ Jumlah } \\
\cline { 2 - 4 } & Laki-laki & Perempuan & \\
\hline IIa & 17 & 11 & 28 \\
\hline IIb & 19 & 10 & 29 \\
\cline { 2 - 4 } & 36 & 21 & 57 \\
\hline
\end{tabular}

\section{HASIL DAN PEMBAHASAN}

Berdasarkan tes uji kompetensi Matematika pada pokok bahasan penjumlahan dua bilangan tanpa menyimpan yang dilaksanakan pada hari senin 22 September 2014, dimana dilakukan tes pra tindakan yang bertujuan untuk mengetahui penguasaan peserta didik dalam materi penjumlahan dua bilangan. Dalam proses pembelajarannya dilaksanakan secara konvensional dan belum menggunakan media sedotan. Ternyata hasilnya kurang memuaskan, padahal guru sudah berupaya semaksimal mungkin menjelaskan materi tersebut kepada peserta didik. 
Berdasarkan hasil pra tindakan dapat terlihat bahwa hasil belajar peserta didik kelas IIa SD Negeri 064960 Medan Polonia dengan ketuntasan secara klasikal sebesar $28,57 \%$ termasuk dalam kriteria sangat kurang tercapai. Jadi, dapat diketahui tingkat ketercapaian keberhasilan pembelajaran belum memenuhi syarat ketuntasan belajar secara klasikal yaitu $85 \%$.

Siklus I

Pada tahap perencanaan ini peneliti menyusun rencana pembelajaran siklus I meliputi standar kompetensi, kompetensi dasar, indikator dan tujuan pembelajaran serta menyiapkan tes (pre-test dan posttest) untuk pembelajaran siklus I pada materi penjumlahan dua bilangan tanpa menyimpan dengan menggunakan media konkret sedotan. Lembar pengamatan aktivitas peserta guru dan peserta didik pada saat pembelajaran yang digunakan untuk menilai aktivitas belajar dalam pembelajaran Matematika.

Pada tahap pelaksanaan tindakan, guru harus menjelaskan rencana kegiatan melaksanakan pembelajaran yang telah dibuat berdasarkan rencana pembelajaran.

Pengamatan untuk melihat hasil aktvitas guru dan peserta didik. Adapun hasil penelitian dalam siklus
I ini terhadap dua pengamat yaitu guru dan mahasiswa yang dicatat.

Data hasil belajar diperoleh dari tes yang dilakukan setelah selesai pelaksanaan kegiatan penelitian tindakan kelas siklus I. Soal yang diberikan sama dengan soal pada saat melakukan pra tindakan yang berjumlah sepuluh butir soal.

Aktivitas peserta didik dalam pembelajaran secara klasikal memperoleh skor $57,14 \%$ dengan kriteria sedang. Berdasarkan dengan ketuntasan aktivitas belajar peserta didik yang sudah ditentukan yaitu $\geq$ 45 dan secara klasikal mencapai skor $85 \%$ maka aktivitas peserta didik perlu ditingkatkan lagi.

Berdasarkan tabel hasil post test siklus I diketahui hasil belajar peserta didik kelas IIa SD Negeri 064960 Medan Polonia dengan ketuntasan secara klasikal 64,28\% termasuk dalam kriteria kurang tercapai. Sehingga hasil posttest siklus I belum memenuhi syarat ketuntasan belajar secara klasikal dan sebagian besar peserta didik belum mencapai ketuntasan belajar yang ditetapkan untuk mata pelajaran matematika yaitu 60 .

Refleksi akan dilakukan setelah semua kegiatan pembelajaran siklus I telah selesai. Pada siklus I peneliti dalam proses pembelajaran menggunakan media sedotan untuk 
Megawati : Upaya Meningkatkan Hasil Belajar ..

meningkatkan hasil belajar Siklus II

matematika.

Berdasarkan hasil dari diskusi yang dilakukan peneliti dengan 2 orang observer, kekurangan peneliti pada siklus I yaitu:

1. Masih kurang maksimal dalam mengkondisikan kelas pada saat pembelajaran.

2. Masih ada peserta didik yang ribut pada saat pembelajaran berlangsung sehingga peneliti dalam meenyampaikan materi tentang penjumlahan dua bilangan tanpa menyimpan masih kurang tercapai.

Berdasarkan hasil refleksi terhadap pembelajaran perlu adanya perbaikan yang dilakukan dari segi proses maupan hasil belajar peserta didik yang masih menunjukkan bahwa tindakan siklus I belum menunjukkan keberhasilan yang maksimal sehingga peneliti harus melanjutkan pada siklus II untuk melihat sejauh mana keberhasilan yang dicapai dalam meningkatkan hasil belajar matematika menggunakan media sedotan. Semua kekurangan dalam siklus I akan diperbaiki kembali pada siklus II dan peneliti akan melanjutkan ke siklus II.

Pada hasil refleksi siklus I
masih ada kekurang dalam penelitiannya yaitu:

1. Masih kurang maksimal dalam mengkondisikan kelas pada saat pembelajaran.

2. Masih ada peserta didik yang ribut pada saat pembelajaran berlangsung sehingga peneliti dalam menyampaikan materi tentang penjumlahan dua bilangan tanpa menyimpa masih kurang tercapai.

Jadi didalam perencanaan pada siklus II ini peneliti harus lebih maksimal lagi mengkontrol peserta didik agar tidak ribut dan suasana kelas lebih dapat kondusif pada saat pembelajaran berlangsung. Pada perencanaan siklus II ini peneliti menyusun rencana pembelajaran yang sama seperti siklus I yang juga meliputi standar kompetensi, kompetensi dasar, indikator dan tujuan pembelajaran serta menyiapkan post test. Lembar pengamatan aktivitas peserta guru dan peserta didik pada saat pembelajaran yang digunakan untuk menilai aktivitas belajar dalam pembelajaran Matematika.

Pada tahap pelaksanaan guru harus menjelaskan rencana kegiatan melaksanakan pembelajaran yang telah dibuat berdasarkan rencana pembelajaran. Sedangkan tahap

p-ISSN 2407-4934

e-ISSN 2355-1747 
pengamatan, dilakukan untuk melihat hasil aktvitas guru dan peserta didik. Adapun hasil penelitian dalam siklus II ini terhadap dua pengamat juga yaitu guru dan mahasiswa yang dicatat dalam lembar pengamatan aktivitas guru dan peserta didik pada saat pembelajaran.

Data situasi belajar mengajar merupakan data tentang situasi belajar aktivitas peneliti dan peserta didik pada saat penelitian kelas berlangsung. Data tersebut diperoleh dari hasil observasi yang diisi oleh observer pada lembar observasi.

Berdasarkan data hasil belajar diperoleh aktivitas peserta didik dalam pembelajaran secara klasikal memperoleh skor $100 \%$ dengan kategori sangat baik. Berdasarkan dengan indikator ketuntasan aktivitas belajar peserta didik yang sudah ditentukan yaitu $\geq 45$ dan secara klasikal mencapai skor $85 \%$ maka aktivitas peserta didik dikatakan tuntas.

Berdasarkan data tabel 15 siklus II terlihat bahwa nilai hasil belajar Matematika peserta didik kelas IIa SD Negeri 064960 Medan Polonia, tingkat ketercapaian keberhasilan pembelajaran sudah memenuhi syarat ketuntasan klasikal yakni $100 \%$ peserta didik mencapai ketuntasan belajar sedangkan peningkatan hasil belajar juga termasuk dalam kategori tinggi yakni 0,87 sehingga penelitian ini tidak perlu dilanjutkan ke siklus selanjutnya atau siklus III.

Data refleksi dilakukan setelah kegiatan pembelajaran siklus II selesai. Saat melakukan refleksi ini, peneliti dan dua orang pengamat berdiskusi untuk membahas kegiatan belajar yang telah dilakukan berdasarkan hasil pengamatan. Pada siklus II peneliti tetap menggunakan media sedotan dalam proses pembelajaran matematika. Selanjutnya peneliti membagikan soal kepada peserta didik dan media untuk digunakan dalam menjawab soal post test. Pada siklus I peneliti meminta beberapa orang peserta didik untuk maju kedepan untuk mengerjakan soal penjumlahan dua bilangan tanpa menyimpan.

Dari hasil diskusi tersebut peneliti mendapatkan saran dari pengamat yaitu agar dimana dalam penggunaan media sedotan sebaiknya terus diterapkan dalam proses pembelajaran terutama pada pelajaran matematika untuk meningkatkan pemahaman penjumlahan dua bilangan tanpa menyimpan. Karena dengan adanya penggunaan media sedotan mampu meningkatkan keaktifan peserta didik secara tdak langsung juga meningkatkan hasil belajar matematika terutama pada materi penjumlahan dua bilangan tanpa menyimpan dalam proses pembelajaran matematika. Hal ini 
dapat dilihat dari hasil tabel - tabel di atas.

Dalam penelitian tindakan kelas ini ada dua hipotesis tindakan kelas yang akan diuji kebenarannya yaitu:

1. Aktivitas Peserta Didik Pada Mata Pelajaran Matematika Kelas IIA Dengan Cara Menggunakan Media Sedotan.

Aktivitas peserta didik pada pembelajaran Matematika dengan cara menggunakan media konkret sedotan pada SDN Langkai Palangka Raya dapat diuji kebenaran datanya. Berdasarkan Indikator ketercapaian aktivitas setiap peserta didik pada siklus I yang diperoleh oleh peserta didik dengan persentase $57,14 \%$ kurang tercapai, sedangkan pada siklus II skor yang diperoleh peserta didik dengan persentase $100 \%$ dengan kriteria sangat baik. Pencapaian ini telah memenuhi syarat ketuntasasn aktivitas belajar peserta didik berdasarkan indikator ketercapaian baik secara individu maupun secara klasikal. Hal ini menunjukkan bahwa dengan penggunaan media konkret sedotan dapat membuat peserta didik lebih aktif lagi.

2. Hasil Belajar Peserta Didik Pada Mata Pelajaran Matematika Kelas IIA Dengan Menggunakan Media Konkret Sedotan.
Ada peningkatan hasil belajar peserta didik pada saat pembelajaran Matematika dengan menggunakan media konkret sedotan pada SD Negeri 064960 Medan Polonia dapat diuji. Berdasarkan indikator ketercapaian hasil belajar setiap peserta didik dari mulai pra tindakan sampai siklus II yang diperoleh peserta didik mengalami peningkatan secara signifikan yaitu pra tindakan dengan rata-rata 43,92 dengan ketuntasan $28,57 \%$ kriteria sangat kurang tercapai, sedangkan pada siklus I dengan rata-rata 61,78 dengan ketuntasan klasikal 64,28\% dengan kriteria cukup tercapai, sedangkan pada siklus II dengan ratarata 93,57 dengan ketuntasan 100\% dengan kriteria sangat tercapai. Pencapaian ini memenuhi syarat kriteria ketuntasan minimal KKM belajar peserta didik berdasarkan indikator ketercapaian baik secara individu maupun secara klasikal.

\section{Pembahasan}

1. Hasil Pengamatan Aktivitas Peserta Didik Pada Saat Penggunaan Media Konkret Sedotan.

Berdasarkan pengamatan yang telah dilakukan hasil terhadap aktivitas peserta didik dalam pembelajaran Matematika dilihat dari lembar observasi setiap siklus diperoleh sebagai berikut: 
Presentase Hasil Observasi Aktivitas Peserta Didik

\begin{tabular}{|l|l|l|}
\hline Siklus & $\begin{array}{l}\text { Jumlah peserta } \\
\text { didik } \\
\text { mencapai } \geq \mathbf{4 5}\end{array}$ & Persentase \\
\hline Siklus & 16 & $57,14 \%$ \\
\hline
\end{tabular}

Berdasarkan tabel di atas melalui perbaikan pembelajaran dengan menggunakan media konkret sedotan pada proses pembelajaran Matematika yang dilakukan oleh peneliti di kelas IIa SD Negeri 064960 Medan Polonia Tahun Ajaran 2014/2015, menunjukkan ada peningkatan aktivitas peserta didik pada siklus I dan siklus II.

2. Nilai Hasil Belajar Peserta Didik Setelah Menggunakan Media Konkret Sedotan

Hasil belajar peserta didik setelah menggunakan media konkret sedotan mengalami peningkatan pada mata pelajaran matematika dalam materi penjumlahan dua bilangan tanpa menyimpan. Hal ini dikarenakan adanya alat bantu yang $100 \%$ dengan kriteria sangat baik. Ada peningkatan hasil belajar peserta didik dalam pelajaran matematika dengan menggunakan media konkret sedotan, hal ini dapat dilihat dari perbedaan nilai rata-rata peserta didik sebelum melaksanakan penelitian tindakan kelas. Sebelum melaksanakan penelitian tindakan kelas atau dilihat dari tes pra tindakan nilai rata-rata yang diperoleh adalah 43,92dan ketuntasan secara klasikal $28,57 \%$ dengan kategori sangat kurang tercapai. Nilai rata-rata pada siklus I adalah 61,78 dan ketuntasan secara klasikal 64,28\% dengan kategori cukup tercapai sedangkam N-Gain pada siklus I adalah 0,34 dalam kategori sedang. Maka siklus I masih dianggap belum berhasil. Nilai rata pada siklus II adalah 93,57 dan ketuntasan secara klasikalnya $100 \%$ dengan kategori sangat tercapai sedangkan N-Gain pada siklus II adalah 0,87 dengan kategori tinggi.

\section{SIMPULAN}

Berdasarkan hasil penelitian maka dapat disimpulkan bahwa ada peningkatan yang sangat signifikan antara hasil pra tindakan sebelum melakukan penelitian tindakan kelas dengan hasil post tes pada siklus II.

Untuk meningkatkan kualitas pembelajaran pada mata pelajaran Matematika, ada beberapa rekomendasi yang penulis rasa perlu untuk diperhatikan diantaranya yaitu:

1. Bagi kepala sekolah diharapkan agar dapat memberikan motivasi kepada guru-guru untuk meningkatkan hasil belajar peserta didik khususnya dengan 
menggunakan media konkret sedotan.

2. Bagi guru diharapkan agar dapat lebih kreatif dalam proses pembelajaran di kelas, salah satunya dengan menggunakan media konkret sedotan pada pokok bahasan penjumlahan dua bilangan tanpa menyimpan yang dapat meningkatkan hasil belajar peserta didik.

3. Bagi penelitian selanjutnya hasil penelitian ini diharapkan menjadi acuan bagi peneliti lain dengan melakukan langkahlangkah yang tepat sehingga kekurangan yang masih ada dari penelitian ini dapat disempurnakan lagi.

\section{DAFTAR RUJUKAN}

Arsyad, A. 2011. Media Pembelajaran. Jakarta: PT RajaGrafindo Persada.

Arikunto, S. 2012. Penelitian Tindakan Kelas. Jakarta: PT Bumi Aksara.

Arifin, Z. 2012. Evaluasi Pendidikan. Bandung: PT. Remaja Rosdakarya.

Aunurahman. 2010. Belajar dan Pembelajaran. Bandung: Alfabeta.

Dimyati \& Mudjiono. 2010. Belajar dan Pembelajaran. Jakarta: PT. Rineka Cipta.
Djamarah, B. 2010. Strategi Belajar Mengajar. Jakarta: PT. Rineka Cipta.

Hamalik, O. 2011. Proses Belajar Mengajar. Jakarta: Bumi Askara.

Heruman. 2008. Model Pembelajaran Matematika Disekolah Dasar. Bandung: PT. Remaja Rosdakarya.

Jennah, R. 2009. Media Pembelajaran. Banjarmasin: Antasari Perss.

Kunandar. 2012. Penelitian Tindakan Kelas. Jakarta: PT RajaGrafindo Persada.

Musfiqon. 2012. Metodologi Penelitian. Jakarta: Prestasi Pustakaraya.

Purwanto, N. 2010. Evaluasi Pengajaran. Bandung: PT. Remaja Rosdakarya.

Purwanto, N. 2008. Prinsip-Prinsip dan Teknik Evaluasi Pengajaran. Bandung: PT. Remaja Rosdakarya. 